\title{
An innovative technique for extracorporeal carbon dioxide removal featuring an electrodialysis unit: an in-vitro experiment
}

\author{
A Zanella*, D Ferlicca, S Abd El Aziz El Sayed Deab, S Colombo, S Spina, S Sosio, M Introna, D Ceriani, D Salerno, \\ A Pesenti
}

From ESICM LIVES 2015

Berlin, Germany. 3-7 October 2015

\section{Introduction}

Acidification of blood entering the membrane lung (ML) converts bicarbonate ions into dissolved gaseous $\mathrm{CO}_{2}$, increasing the $\mathrm{pCO}_{2}$ transmembrane gradient and thus the extracorporeal carbon dioxide removal $\left(\mathrm{ECCO}_{2} \mathrm{R}\right)$ [1]. Extracorporeal blood acidification has previously been achieved by infusion of lactic acid, which proved to be effective in rising $\mathrm{ECCO}_{2} \mathrm{R}$ but determined a mild increase of total $\mathrm{CO}_{2}$ production and induced a slight degree of metabolic acidosis [2], thus limiting the overall effectiveness of such treatment.

\section{Objectives}

The aim of this study is to evaluate in-vitro the efficiency of an $\mathrm{ECCO}_{2} \mathrm{R}$ technique enhanced by an innovative acidification system featuring an electrodialysis unit, which does not require the infusion of any exogenous acid.

\section{Methods}

The circuit used for this experiment included a bloodcircuit, including a dialyzer, and a dialysiscircuit, a closed loop circuit featuring an electrodialysis (ED) cell and an adult polypropylene membrane lung (Quadrox-i, Maquet). An aqueous polyelectrolyte carbonated solution (CB 32, Novaselect, pH $7.33 \pm 0.02, \mathrm{HCO}_{3}{ }^{-} 32 \mathrm{mmol} / \mathrm{l}$ ) was used as a substitute for blood and flowed into the hemofilter at $250 \mathrm{ml} / \mathrm{min}$. The ED unit is able to transfer electrolytes across a semipermeable membrane proportionally to the applied amperage. The ED cell was therefore used to increase chloride concentrations in the dialysate, thus reducing $\mathrm{pH}$ before the membrane lung without infusing of any

Università degli Studi di Milano Bicocca, Monza, Italy exogenous compound. Five different amperages (0, 2, 4, 6 and $8 \mathrm{Amp}$ ) were tested. At the end of each step samples were withdrawn from blood and dialysiscircuit, and $\mathrm{CO}_{2}$ removal $\left(\mathrm{VCO}_{2}\right)$ was measured.

\section{Results}

The application of ED technique determined an increase in chloride concentration before the ML up to $7.1 \pm 1$ $\mathrm{mEq} / \mathrm{L}$ (at $8 \mathrm{Amp}$ ) and a consequent reduction in $\mathrm{pH}$ from $7.48 \pm 0.01$ to $6.5 \pm 0.04$. This resulted in a significant raise of $\mathrm{CO}_{2}$ extraction, up to a $\mathrm{VCO}_{2}$ increase of $237 \%$ at $8 \mathrm{Amp}$, (see Figure 1).

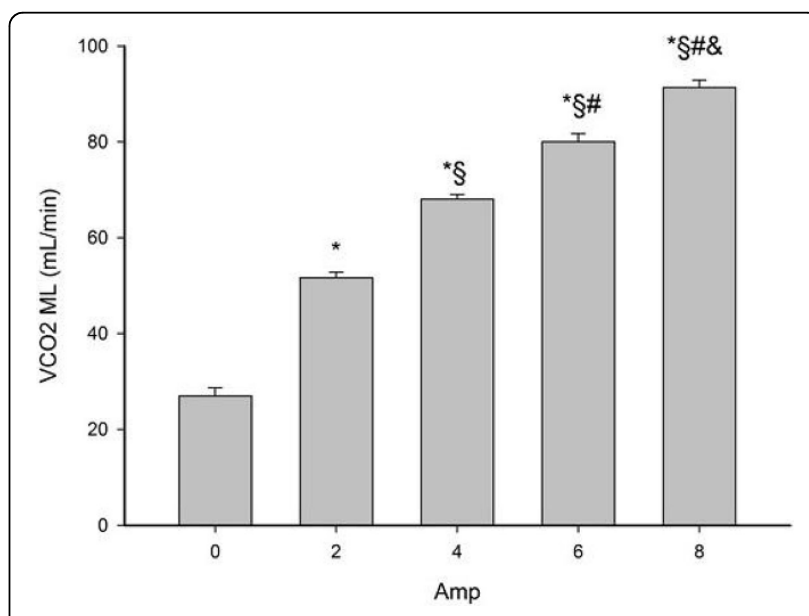

Figure 1 Membrane lung carbon dioxide removal $\left(\mathrm{VCO}_{2} \mathrm{ML}\right)$ at increasing amperages. *: $p<0.001$ vs 0 Amp, $: p<0.001$ vs 2 Amp, \#: $p<0.001$ vs 4 Amp, \&: $p<0.001$ vs 6 Amp

(C) 2015 Zanella et al.; This is an Open Access article distributed under the terms of the Creative Commons Attribution License (http:// creativecommons.org/licenses/by/4.0), which permits unrestricted use, distribution, and reproduction in any medium, provided the original work is properly cited. 


\section{Conclusions}

The tested prototype $\mathrm{ECCO}_{2} \mathrm{R}$ device, enhanced by an electrodialysis unit, proved to be effective in increasing carbon dioxide removal, proportionally to the applied amperage. Future experimental studies are required to evaluate in-vivo this innovative technique.

Published: 1 October 2015

\section{References}

1. Zanella A, Mangili P, Redaelli S, Scaravilli V, Giani M, Ferlicca D, et al: Regional Blood Acidification Enhances Extracorporeal Carbon Dioxide Removal: a 48 Hours Animal Study. Anesthesiology 2014, 120(2):416-424.

2. Zanella A, Giani M, Redaelli S, Mangili P, Scaravilli V, Ormas V, et al: Infusion of $2.5 \mathrm{meq} / \mathrm{min}$ of lactic acid minimally increases $\mathrm{CO}_{2}$ production compared to an isocaloric glucose infusion in healthy anesthetized, mechanically ventilated pigs. Crit Care 2013, 17(6):R268.

doi:10.1186/2197-425X-3-S1-A501

Cite this article as: Zanella et al:: An innovative technique for extracorporeal carbon dioxide removal featuring an electrodialysis unit: an in-vitro experiment. Intensive Care Medicine Experimental 2015 3(Suppl 1):A501.

\section{Submit your manuscript to a SpringerOpen ${ }^{\mathcal{O}}$ journal and benefit from:}

- Convenient online submission

- Rigorous peer review

- Immediate publication on acceptance

- Open access: articles freely available online

- High visibility within the field

- Retaining the copyright to your article 